A Genetic Analysis of Lesser Snow Goose Families

Author(s): F. Cooke and P. J. Mirsky

Reviewed work(s):

Source: The Auk, Vol. 89, No. 4 (Oct., 1972), pp. 863-871

Published by: University of California Press on behalf of the American Ornithologists' Union

Stable URL: http://www.jstor.org/stable/4084116

Accessed: 09/04/2012 16:53

Your use of the JSTOR archive indicates your acceptance of the Terms \& Conditions of Use, available at http://www.jstor.org/page/info/about/policies/terms.jsp

JSTOR is a not-for-profit service that helps scholars, researchers, and students discover, use, and build upon a wide range of content in a trusted digital archive. We use information technology and tools to increase productivity and facilitate new forms of scholarship. For more information about JSTOR, please contact support@jstor.org. 


\section{A GENETIC ANALYSIS OF LESSER SNOW GOOSE FAMILIES}

\section{F. Cooke AND P. J. Mirsky}

Although genetic polymorphism is well-documented with respect to avian plumage color, surprisingly few studies have investigated the genetic basis of the polymorphism. The major limitations on studies of this nature have been an inadequate sample size and a lack of expression of the polymorphic character at some stage in the life cycle. In the Lesser Snow Goose, Anser caerulescens caerulescens, these limitations do not apply and it has been possible to undertake an investigation into the blue and white phases of this species. Earlier work has indicated that the dimorphism is regulated by a single pair of alleles with the blue phase dominant over white (Cooke and Cooch, 1968). This conclusion was based on analyses where data from several different families were pooled to give genetic ratios. This method, while adequate to show the probable genetic basis for the polymorphism, would have been more convincing if individual families had been available for analysis. Further, it gave no clear indication as to whether the gene controlling color was sex-linked or not.

During the summers of 1968,1969 , and 1970 it was possible to collect individual family data from the La Pérouse Bay colony near Churchill, Manitoba. An analysis of data from families collected from this colony has supported the earlier findings of Cooke and Cooch as well as demonstrating that the gene is autosomal and not sex linked.

\section{METHODS}

Collection of data.-In the breeding colony, nests were marked with stakes and numbered several days prior to hatch. Much of the colony was marked in this manner, and it is thought that no sampling bias exists. At hatch both parents remain near the nest, and at this time the phenotypes of parents and goslings could be scored. The color phases were recorded according to the criteria of Cooke and Cooch (1968), and little difficulty was encountered in assigning birds a given color category.

Families were recorded only at the marked nest site. If all goslings had not hatched when a given nest was visited, the family was recorded as having only those offspring that had hatched, even though the final family size would presumably be larger. This could give the data some bias if certain genotypes hatch earlier than others. Families with more than five offspring were ignored in the statistical analysis, as it has been shown (Cooch, 1961), and the present study confirms, that large families have a tendency to arise from two or more females laying eggs in the same nest.

Segregation analysis.-A number of features of the Lesser Snow Goose restricted the type of genetic analysis that could be attempted on the sample population. 
TABLE 1

Summary of Famity Data Collected from La Pérouse Bay, 1968-1970

\begin{tabular}{|c|c|c|c|c|c|}
\hline \multirow{3}{*}{$\begin{array}{l}\text { Parental } \\
\text { pair bonds }\end{array}$} & \multicolumn{5}{|c|}{ Gosling phenotype } \\
\hline & \multicolumn{2}{|c|}{$\begin{array}{l}\text { White } \\
\text { phase }\end{array}$} & \multicolumn{2}{|c|}{$\begin{array}{l}\text { Blue } \\
\text { phase }\end{array}$} & \multirow[b]{2}{*}{ Totals } \\
\hline & No. & $\%$ & No. & $\%$ & \\
\hline $\mathrm{W} \hat{o} \times \mathrm{W}$ 우 & 3,099 & 98.2 & 45 & 1.4 & 3,144 \\
\hline $\mathrm{W}$ o $\times \mathrm{B}$ 우 & 109 & 43.4 & 142 & 56.6 & 251 \\
\hline B $\hat{\delta} \times \mathrm{W}$ o & 195 & 40.5 & 287 & 59.5 & 482 \\
\hline B $\hat{\sigma} \times \mathbf{B}$ 우 & 77 & 9.2 & 761 & 90.8 & 838 \\
\hline Totals & 3,480 & 73.8 & 1,235 & 26.2 & 4,715 \\
\hline
\end{tabular}

a) It has been shown that white-bellied blue birds have a greater tendency to be heterozygous than dark-bellied blue birds (Cooke and Cooch, 1968). Heterozygosity was established by the presence of white goslings with blue parents. These findings were confirmed in the present analysis. As a particular blue bird could not be classified diagnostically as to whether it was heterozygous or homozygous on the basis of plumage color alone, it was necessary to assume complete dominance in the analysis.

b) Although birds attain sexual maturity at 2 years of age, they rarely breed successfully before their third and sometimes their fourth summer (Cooch, 1958). Therefore, within the scope of this inquiry, it has been impossible to analyze more than two generations of family data, and backcross and intercross data are unavailable.

c) Lesser Snow Geese have a rather small clutch size, rarely averaging over four eggs (Cooch, 1958).

d) Female geese on occasion will dump eggs in nests other than their own.

e) Strong positive assortative mating for color was observed on the colony. This precluded the use of the Hardy-Weinberg equilibrium in genetic calculations.

At least the first three problems listed are reminiscent of difficulties encountered in human genetic analyses, and Hogben (1945) described a test to analyze the genetic basis of suspected rare genetical diseases in man. Smith (1955) pointed out that this test is equally applicable to common genes. This test, which is an a priori test, is appropriate to the present analysis as we are testing the hypothesis that a single gene mode of inheritance determines the color phases of the Lesser Snow Goose. Random mating is not a prerequisite for the successful application of this test.

In general the test analyzes the segregation ratios of progeny from Blue $\times$ Blue $(B \times B)$ and Blue $\times$ White $(B \times W)$ matings. From such matings the genotype of phenotypically dominant parents can be established as heterozygous, if one or more of the progeny derived from the cross are recessive. Not all families from such matings will segregate, and the ratio of segregating to nonsegregating families will be dependent on family size.

For each type of mating, $\mathrm{B} \times \mathrm{B}$ and $\mathrm{B} \times \mathrm{W}$, it is possible to arrange all families with at least one recessive offspring according to sibship size. The genotypes of the parents in this sample will be $\mathrm{Bb} \times \mathrm{Bb}$ and $\mathrm{Bb} \times \mathrm{bb}$. For each sibship size, the observed number of recessive offspring can be compared with an expected number 
TABLE 2

A priori Segregation Analysis for B $\times$ B Matings Sampled at la Pérouse Bay, 1968-1970

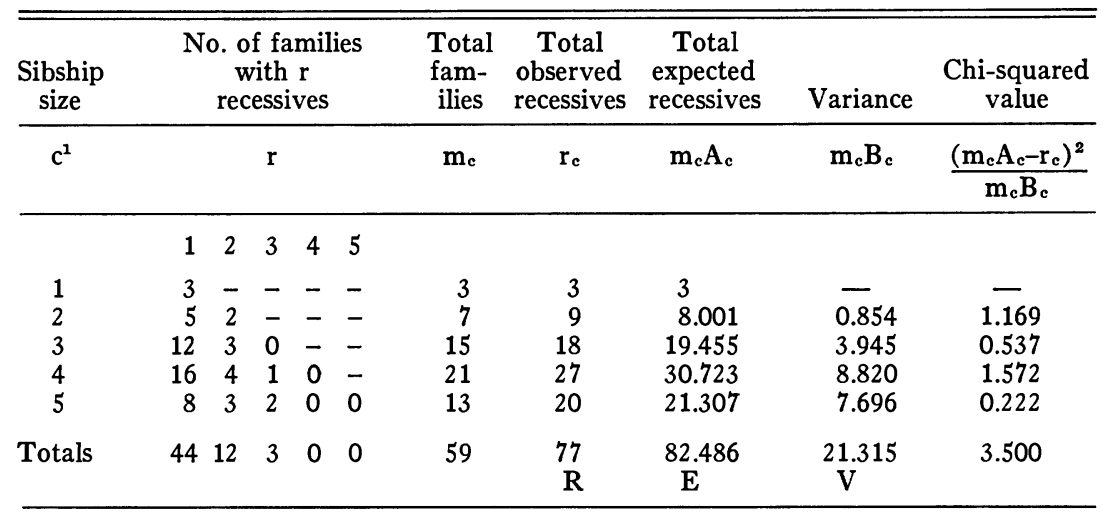

${ }^{1}$ Symbolism is from Smith (1955).

assuming a single gene mode of inheritance. The method of calculating the expected values is well-reviewed by Smith (1955). It consists of calculating the relative frequencies of families with $1,2 \ldots$... c recessives for the families of sibship size $c$, on the basis of the truncated binomial distribution. Constants for each sibship size $A_{c}$ and $a_{c}$ (for $B \times B$ and $B \times W$ crosses respectively), have been calculated (Smith 1955), and these constants multiplied by the number of families in the particular sibship size give the number of expected recessives for that sibship size. Variances are derived using the constants $B_{c}$ and $b_{c}$ calculated by Smith. Finally the sum of the observed number of recessive progeny from each sibship size may be compared to the sum of the calculated expected values. This tests for agreement between observed segregation ratios and those expected, assuming in this case a single gene mode of inheritance.

\section{RESULTS}

Segregation analysis.-Family data sampled from the La Pérouse Bay colony for the years 1968-70 are summarized in Table 1. Data from the 3 study years have been combined.

Tables 2 and 3 list family data from $\mathbf{B} \times \mathbf{B}$ and $\mathbf{B} \times \mathrm{W}$ matings according to sibship size. Expected numbers of recessive offspring for each sibship size are calculated assuming a single gene mode of inheritance with blue dominant over white. As stipulated earlier, only families with at least one recessive offspring are included in the segregation analysis.

The difference between total observed and expected values may be tested for significance according to the equation $\chi^{2}{ }_{1}=\frac{(R-E)^{2}}{V}$ where $R$ is the total observed recessives, $\mathrm{E}$ is the total expected recessives, and $\mathrm{V}$ is the total variance. 
TABLE 3

A priori Segregation Analysis for $\mathrm{B} \times \mathrm{W}$ Mating Sampled at la Pérouse Bay, 1968-1970

\begin{tabular}{|c|c|c|c|c|c|c|c|c|c|c|}
\hline $\begin{array}{l}\text { Sibship } \\
\text { size }\end{array}$ & & $\begin{array}{l}\text { o. of } \\
\text { w } \\
\text { rece }\end{array}$ & $\begin{array}{l}\text { f far } \\
\text { ith } \\
\text { essiv }\end{array}$ & & & $\begin{array}{l}\text { Total } \\
\text { fam- } \\
\text { ilies }\end{array}$ & $\begin{array}{c}\text { Total } \\
\text { observed } \\
\text { recessives }\end{array}$ & $\begin{array}{c}\text { Total } \\
\text { expected } \\
\text { recessives }\end{array}$ & Variance & $\begin{array}{l}\text { Chi-squared } \\
\text { value }\end{array}$ \\
\hline \multirow[t]{2}{*}{$c^{1}$} & & & $\mathrm{r}$ & & & $\mathrm{m}_{\mathrm{c}}$ & $r_{c}$ & $\mathrm{~m}_{\mathrm{c}} \mathrm{a}_{\mathrm{c}}$ & $\mathrm{m}_{\mathrm{c}} \mathrm{b}_{\mathrm{c}}$ & $\mathrm{m}_{\mathrm{c}} \mathrm{b}_{\mathrm{c}}$ \\
\hline & 1 & 2 & 3 & 4 & 5 & & & & & \\
\hline 1 & 11 & - & - & - & - & 11 & 11 & 11 & - & - \\
\hline 2 & 16 & 9 & - & - & - & 25 & 34 & 33.325 & 5.550 & 0.082 \\
\hline 3 & 10 & 13 & 9 & - & - & 32 & 63 & 54.848 & 15.680 & 4.238 \\
\hline 4 & 20 & 24 & 17 & 4 & - & 65 & 135 & 138.645 & 50.830 & 0.261 \\
\hline 5 & 5 & 5 & 9 & 1 & 3 & 23 & 61 & 59.363 & 24.886 & 0.108 \\
\hline Totals & 62 & 51 & 35 & 5 & 3 & 156 & $\begin{array}{r}304 \\
\mathrm{R}\end{array}$ & $\begin{array}{c}297.181 \\
\text { E }\end{array}$ & $\begin{array}{l}96.896 \\
\text { V }\end{array}$ & 4.689 \\
\hline
\end{tabular}

${ }^{1}$ Symbolism is from Smith (1955).

From Table 2, $\mathrm{B} \times \mathrm{B}$ matings yield:

$$
\chi^{2}{ }_{1}=\frac{(\mathrm{R}-\mathrm{E})^{2}}{\mathrm{~V}}=\frac{(77-82.486)^{2}}{21.315}=1.41 ; \quad 0.30>p>0.10
$$

These values indicate good agreement with the single gene hypothesis. As a further test of the data, the difference between the sum of chi-squared values for each sibship size and the chi-squared value obtained above constitutes a test for heterogeneity in the data. Thus $\chi^{2}{ }_{3}=3.500-1.412$ $=2.088 ; 070>p>0.50$. The lack of heterogeneity found in the data further supports the single gene hypothesis.

Similarly, from Table $3, \mathrm{~B} \times \mathrm{W}$ matings yield:

$$
\chi^{2}{ }_{1}=\frac{(\mathrm{R}-\mathrm{E})^{2}}{\mathrm{~V}}=\frac{(304-297.181)^{2}}{96.896}=0.48 ; \quad 0.50>p>0.30
$$

As in the case of the $\mathrm{B} \times \mathrm{W}$ mating there is also no heterogeneity detectable in the data, $\chi^{2}{ }_{3}=(4.689-0.480)=4.209 ; 0.30>p>0.10$.

Thus segregation ratios from $\mathrm{B} \times \mathrm{B}$ and $\mathrm{B} \times \mathrm{W}$ matings support the single gene mode of inheritance.

It was now necessary to confirm the autosomal nature of the gene regulating color. Table 4 lists the distribution of offspring from $\mathrm{B} \times \mathrm{B}$ and $\mathrm{B} \times \mathrm{W}$ matings according to sex. In birds the female is the heterogametic sex. Only those goslings that were web-punched as 1-day-old goslings and recaptured later in the banding drives could be used for 
TABLE 4

GosLing Distribution According to Sex ${ }^{1}$

\begin{tabular}{|c|c|c|c|c|c|c|}
\hline \multirow{2}{*}{\multicolumn{3}{|c|}{ Mating }} & \multirow[b]{2}{*}{ Sex } & \multicolumn{2}{|c|}{ No. of Progeny } & \multirow[b]{2}{*}{ Total } \\
\hline & & & & White & Blue & \\
\hline B & $\hat{\imath} \times \mathrm{B}$ & 우 & $\begin{array}{l}\hat{o} \\
\hat{q}\end{array}$ & $\begin{array}{r}7 \\
10\end{array}$ & $\begin{array}{l}77 \\
69\end{array}$ & $\begin{array}{l}84 \\
79\end{array}$ \\
\hline B & $\hat{o} \times W$ & ㅇ & $\begin{array}{l}\hat{\circ} \\
\grave{Q}\end{array}$ & $\begin{array}{l}20 \\
14\end{array}$ & $\begin{array}{l}27 \\
21\end{array}$ & $\begin{array}{l}47 \\
35\end{array}$ \\
\hline & $\hat{o} \times \mathbf{B}$ & q & $\begin{array}{l}\hat{\circ} \\
\stackrel{+}{q}\end{array}$ & $\begin{array}{r}16 \\
7\end{array}$ & $\begin{array}{l}18 \\
20\end{array}$ & $\begin{array}{l}34 \\
27\end{array}$ \\
\hline \multicolumn{4}{|c|}{ TOtaLs } & 74 & 232 & 306 \\
\hline
\end{tabular}

${ }_{1}$ Pooled data from several families.

these data. Assuming sex-linkage, a number of combinations of parental and gosling colors would not be expected. In $\mathrm{B} \times \mathrm{B}$ matings, no white male progeny would be expected. In $\mathrm{W} \hat{o} \times \mathrm{B} i$ matings, all male progeny would be blue, while all female progeny would be white. As can be seen in Table 4, these restrictions are not satisfied. The gene appears therefore to be autosomal.

Nongenetic families.-Although the segregation analysis strongly supports the earlier work of Cooke and Cooch, one major difficulty remains. If the color inheritance in Lesser Snow Geese is the result of a single autosomal gene with blue dominant over white, $\mathrm{W} \times \mathrm{W}$ matings should not yield blue progeny. Table 1 shows 45 (1.4 percent) of the progeny in the La Pérouse Bay population were blue phase.

It is suggested that some of these individuals result from dumping, the laying of eggs in a nest by a female other than the female that incubates and rears the young. It is well-known that dumping occurs in Lesser Snow Geese (Cooch, 1958) and further, that dumping increases with increased disruption on the breeding colony. At the McConnell River colony, a late spring thaw followed by flooding resulted in 11.9 percent of the eggs in nests being of dump origin (MacInnes, et al., 1969). Under normal conditions dumping would be considerably less.

MacInnes determined dump frequencies by noting the addition of more than one egg to a nest in 24 hours during the egg-laying period. This was based on the assumption that Lesser Snow Geese are incapable of laying more than one egg in a day (Cooch, 1958).

Assuming that dumping is random and that blue phase birds are as likely to dump eggs as the white phase, it is possible to estimate the dump frequency at the La Pérouse Bay colony. The dump frequency is defined here as the proportion of goslings that hatch from eggs laid 
TABLE 5

Distribution of Offspring from $\mathrm{W} \times \mathbf{W}$ Matings According to Family Size at La Pérouse Bay, 1968-71

\begin{tabular}{lrrrrrr}
\hline \hline $\begin{array}{c}\text { Family } \\
\text { size }\end{array}$ & $\begin{array}{c}\text { No. of } \\
\text { families }\end{array}$ & $\begin{array}{c}\text { No. of } \\
\text { white } \\
\text { goslings }\end{array}$ & $\begin{array}{c}\text { No. of } \\
\text { blue } \\
\text { goslings }\end{array}$ & Total & Frequency & SD \\
\hline 1 & 9 & 8 & 1 & 9 & 0.1111 & 0.1049 \\
2 & 67 & 117 & 1 & 118 & 0.0085 & 0.0085 \\
3 & 172 & 405 & 9 & 414 & 0.0217 & 0.0072 \\
4 & 350 & 1,134 & 10 & 1,144 & 0.0087 & 0.0027 \\
5 & 273 & 1,013 & 23 & 1,036 & 0.0222 & 0.0046 \\
6 & 117 & 502 & 17 & 519 & 0.0328 & 0.0078 \\
7 & 36 & 151 & 8 & 159 & 0.0503 & 0.0173 \\
8 & 17 & 88 & 6 & 94 & 0.0638 & 0.0252 \\
9 & 10 & 36 & 1 & 37 & 0.0270 & 0.0266 \\
TotALs & 1,051 & 3,454 & 76 & 3,530 & 0.0222 & 0.0025 \\
\hline
\end{tabular}

by a bird other than the incubating female. From Table 1, 45 of 3,144 offspring from $\mathrm{W} \times \mathrm{W}$ mating are blue. Thus, the frequency of dumped blue birds in $\mathrm{W} \times \mathrm{W}$ nests is $\mathrm{x}=45 / 3144=0.014$, and given random dumping, the probability of a bird sampled from any nest being a dumped blue bird is also 0.014 . The total dump frequency for both color phases is then simply $\mathrm{x} / \mathrm{p}$ where $\mathrm{p}$ is the frequency of blue birds on the colony. Over the 3 study years at La Pérouse Bay, the frequency of blue phase goslings has been $\mathrm{p}=0.262$ and the dump frequency is $\mathrm{x} / \mathrm{p}=0.014 / 0.262$ $=0.055$.

One piece of evidence supporting the view that blue goslings in $\mathrm{W} \times \mathrm{W}$ nests result from dumping is the distribution of blue birds from such nests according to family size. This distribution is listed in Table 5. This table includes data collected in 1971 and so is not directly comparable to earlier tables. As can be seen, apart from the 1 and 9 family sizes, which are based on small samples, the frequency of blue birds remains low through five offspring sibships and then increases. If the blue offspring from $\mathrm{W} \times \mathrm{W}$ matings were of genetic origin one would expect the relative frequency of blue offspring to remain constant regardless of family size. This null hypothesis was tested by the $\chi_{1}{ }^{2}$ test. Family sizes 1,2 , and 3 and 7,8 , and 9 were combined for the test as expected values were less than 5. A $x_{1}{ }^{2}$ value of 24.2 was obtained. This corresponds to a probability of less than 0.001 . It seems highly unlikely that this increased frequency of blue birds in larger families can have a genetic explanation, but is readily understandable if one assumes that these blue offspring arise from dumping. From this evidence it was decided to exclude sibships with more than five offspring from the genetic analyses. 
Knowing the frequency of dumping, it is possible to consider the effect of this phenomenon on the data collected at La Pérouse Bay. From the calculated dump frequency, the probability of any blue or white gosling selected from the sample being the result of dumping may be determined. The expected number of dumped birds in each sibship size can then be removed from the raw data. An empirical correcting of this nature is crude as it assumes random dumping of both phases, an assumption that at present is difficult to verify. However it was found that a correction of this nature had little effect on the segregation analysis. The revised distribution of families still fits the single gene hypothesis and lends further support to the conclusions previously established.

\section{Discussion}

Segregation ratios observed for both $\mathrm{B} \times \mathrm{B}$ and $\mathrm{B} \times \mathrm{W}$ matings strongly support the single gene hypothesis as an explanation for color inheritance in the Lesser Snow Geese. Deviant sibships in the form of blue progeny with white parentage have been attributed to nongenetic families created through dumping. The calculated dump frequency is within the limits expected in a natural population and the observed distribution of blue progeny with white parents further supports the dumping hypothesis.

One feature of the blue-white color complex yet to be discussed is the considerable variability in the expression of both phases of the species. This variability has been adequately described by Cooke and Cooch (1968). Although considerable variability has been described within the morphs of both goslings and adults, it is always clear to which phase an individual should be assigned. This absence of intermediate birds further supports the hypothesis of a simple mode of inheritance. The variability observed within the color phases is probably due to the influence of the environment as well as to a complex of modifier genes.

Since the turn of the century there has been considerable controversy regarding the taxonomic status of the color phases of the Lesser Snow Goose. Although the most recent American Ornithologists' Union Checklist (1957) regards the Blue Goose and the Lesser Snow Goose as separate species, most ornithologists concur with Cooch's (1961) findings that they are in fact conspecific. Nevertheless, as recently as 1967, Lemieux and Heyland (1967), on the basis of differential migration patterns of the two, have suggested that the A.O.U. Check-list be adhered to until more substantial evidence supporting classification as a single species can be obtained.

Apart from the obvious color differences, few other differences separate 
the Blue Goose from the Lesser Snow. Cooch (1958) found that white phase birds nest slightly earlier than blue phase birds in late seasons and also noted that blue phase birds tend to have a more easterly migration route and winter distribution than white phase birds from the same colony.

It is interesting to note that in the closely related Ross' Goose, Anser rossii, a similar color dimorphism has been described (Williamson, 1957). It occurs only in the gosling plumage and is also thought to be regulated by a single autosomal gene with the gray phase dominant over the yellow (Cooke and Ryder, 1971). It is tempting to speculate that these two related species evolved from a common ancestor that was already dimorphic.

If the major differences between the two color phases can be explained on the basis of a single gene difference, then it seems unnecessary to postulate that the phases have ever been separated into two allopatric populations, one white and one blue. The present distribution can be explained either by assuming: 1) that relative selective pressures on the two phases vary in different parts of the range or 2) that the present distribution of one of the alleles reflects the spread of that previous rare mutant from an original location. To be more specific, the absence of blue phase birds in the western Arctic may reflect a selective pressure against the blue phase in the west or may indicate that the blue phase was previously an extremely rare form found only in the eastern Arctic that has not yet spread throughout the species' range.

\section{ACKNOWLEDGMENTS}

We gratefully acknowledge the help of the many people who assisted in the collection of the field data from the La Pérouse Bay colony. These include: A. Baldridge, J. Bayly, D. Bighead, H. Burgess, K. Edwards, M. Edwards, G. Finney, B. Guild, L. Lawson, E. Mills, I. Newton, J. Partington, R. Pittaway, R. Rockwell, K. Ross and M. B. Seiger. We would also like to thank P. Colgan for his assistance with certain mathematical aspects of the work.

This research was supported by grants from the Canadian Wildlife Service, the Canadian National Sportsmen's Show, the National Research Council and the Manitoba Department of Mines and Natural Resources. Mirsky was supported by a scholarship from Canadian Industries Limited.

\section{SUMMARY}

The Lesser Snow Goose occurs in two distinct color phases, a blue phase and a white phase. Genetic analysis of a large number of families confirms earlier findings that this dimorphism is determined by a single autosomal gene with blue phase dominant over white. Rare cases where blue goslings hatch from a nest where both parents are white are explained "on the basis of dumping, the laying of eggs in a nest by a 
bird other than the one incubating. The effect of these findings on the taxonomic status of the species is discussed.

\section{Literature Cited}

American Ornithologists' union. 1957. Check-list of North American birds, fifth ed. Baltimore, Amer. Ornithol. Union.

Cooch, F. G. 1958. The breeding biology and management of the Blue Goose. Unpublished Ph.D. dissertation, Ithaca, New York, Cornell Univ.

Coocr, F. G. 1961. Ecological aspects of the Blue-Snow Goose complex. Auk, 78: $72-89$.

Cooch, F. G. 1963. Recent changes in distribution of color phases of Chen $c$. caerulescens. Proc. 13th Intern. Ornithol. Congr., 1184-1194.

Cooke, F., AND F. G. Cooch. 1968. The genetics of polymorphism in the goose, Anser caerulescens. Evolution, 22: 289-300.

Cooke, F., ANd J. P. Ryder. 1971. The genetics of polymorphism in the Ross' Goose, Anser rossii. Evolution, 25: 483-496.

Hogben, L. 1945. Nature and Nurture. London, Allen and Unwin.

Lemieux, I., ANd J. Heyland. 1967. Fall migration of Blue Geese and Lesser Snow Geese from the Koukdjuak River, Baffin Island, Northwest Territories. Natur. Can., 94: 677-694.

MacInnes, C. D., Prevetr, J. P., And L. M. Prevetr. 1969. The 1968 McConnell River Project, Progress Report. Unpublished report to the Canadian Wildlife Service.

Smith, C. A. B. 1955. Test for segregation ratios in family data. Ann. Hum. Genet., 20: 257-65.

Wirliamson, M. H. 1957. Polymorphism in Ross' Goose (Anser rossii) and the detection of genetic dominance from field data. Ibis, 99: 516-518.

Department of Biology, Queen's University, Kingston, Ontario, Canada. Accepted 18 November 1971. 